\title{
Anxiety in Pregnant Women During Coronavirus (Covid-19) Pandemic in East Java, Indonesia
}

\author{
Zakkiyatus Zainiyah, Eny Susanti \\ Profesional Midwives Study Program, Institute of Health Science Ngudia Husada Madura, Indonesia
}

\begin{abstract}
The 2019 coronavirus pandemic has been recognized as a trigger for anxiety, especially in pregnant women. Pregnant women are among those with a high-risk for contracting coronavirus, not only for themselves but also for the unborn child. Continuous information is needed for pregnant women to avoid anxiety because anxiety will result in complications for both mother and child, such as low birth weight baby and postpartum psychological disorder. The purpose of this study was to identify the prevalence of anxiety in pregnant women during the Coronavirus pandemic in Madura, East Java, Indonesia. This study was a cross-sectional descriptive study conducted from April 13 to May 8, 2020. Data were collected using a Google form distributed to all pregnant women in the Madura Region based on the list of pregnant women from the midwives in each city in this region. Seventy pregnant women returned the completed form, and data were analyzed using frequency tables and percentages. Results showed that $31.4 \%$ of pregnant women experienced very severe anxiety, $12.9 \%$ experienced severe anxiety, and the remainings did not experience anxiety. In conclusion, the coronavirus pandemic indeed increases anxiety in pregnant women which will need to be addressed to avoid negative impacts on the mother and unborn child. Counseling is needed to reduce anxiety by asking the women to stay at home, wash their hands, wear masks, eat nutritious food, have their pregnancy checked, perform exercise for pregnant women at home, and seek for help when facing emergencies.
\end{abstract}

Key words: Anxiety, Coronavirus (Covid-19), pandemic, pregnancy

\section{Tingkat Kecemasan Ibu Hamil pada Masa Pandemi Virus Corona (Covid-19) di Jawa Timur, Indonesia}

\begin{abstract}
Abstrak
Pandemi virus corona 2019 ini menyebabkan kecemasan, terutama pada ibu hamil, karena ibu hamil merupakan kelompok risiko tinggi untuk tertular virus corona, terutama pada janin yang dikandungnya, sehingga diperlukan informasi secara terus menerus kepada ibu hamil supaya tidak terjadi kecemasan, karena kecemasan ini akan berakibat komplikasi pada ibu dan janinnya. Dampak kecemasan pada ibu hamil dan janin adalah berat badan lahir rendah dan gangguan psikologis pada ibu setelah melahirkan. Tujuan penelitian ini mengidentifikasi tingkat kecemasan ibu hamil di masa pandemi virus corona di wilayah Madura, Jawa Timur. Penelitian ini dilakukan tanggal 13 April sampai dengan 8 Mei 2020 dan merupakan penelitian desktriptif dengan menggunakan google form yang disebarkan ke seluruh ibu hamil di Wilayah Madura melalui bidan yang ditunjuk setiap kota yang ada di Madura. Tujuh puluh ibu hamil mengembalikan formulir yang telah diisi dan data dianalisis menggunakan tabel frekuensi dan persentase. Hasil penelitian menunjukkan bahwa 31.4\% mengalami kecemasan sangat berat, $12.9 \%$ mengalami kecemasan berat, dan sisanya ibu tidak mengalami kecemasan atau dalam keadaan normal. Simpulan, pandemi virus corona memang meningkatkan kecemasan pada ibu hamil yang perlu diatasi untuk menghindari dampak negatif pada ibu dan janinnya. Konseling diperlukan untuk mengurangi kecemasan dengan meminta ibu-ibu untuk tinggal di rumah, mencuci tangan, memakai masker, makan makanan bergizi, memeriksakan kehamilannya, melakukan senam ibu hamil di rumah, dan mencari pertolongan saat menghadapi keadaan darurat.
\end{abstract}

Kata kunci: Kecemasan, kehamilan, pandemi, viruscorona (covid-19)

Corresponding Author: Zakkiyatus Zainiyah, Profesional Midwives Study Program, Institute of Health Science Ngudia Husada Madura, : Jl. RE Martadinata, No.45, Mlajah, Bangkalan, Madura, Indonesia, Email: zzainiyah@gmail.com 


\section{Introduction}

The coronavirus disease of 2019, or known simply as COVID-19, is an airborne viral respiratory disease first identified in Wuhan, China, in December 2019 that spreads rapidly and can cause death. There is very limited data on the impacts of COVID-19 on pregnant women. However, it is assumed that it can increase the risk of pregnancy complications, requiring optimization of management, especially in health care facilities, through continuous monitoring of both mother and fetus. ${ }^{1}$

Pregnancy is a condition in which partial immunity and physiological changes often occurs, making pregnant women more susceptible to viral infections with a higher morbidity, even with seasonal influenza events. Therefore, the COVID-19 pandemic can have a serious impact on pregnant women. Transmission of the virus from human to human has been proven and pregnant women need to have good knowledge about this disease. Without good knowledge, pregnant women may experience anxiety that will physically affect their unborn child ${ }^{2,3}$. The physiological changes in pregnant women are a result of the normal adaptations experienced by a woman to better accommodate the embryo or fetus and ensure that the fetus grows well and receives adequate nutrition. During this period, women are more susceptible to any threats that will lead to psychological and physiological threats. These changes often make pregnant women experience excessive stress and anxiety. ${ }^{4,5}$ These will, in turn, trigger a physiological response and cause a decrease in immunity. 6,7

Psychological stress, such as fear and anxiety, increases the production of stress hormones, including adrenaline and cortisol. When a pregnant woman is able to cope with stress and anxiety, the impact on physical changes as a normal part of pregnancy is small that the stress can be considered as mild. Anxiety, as a response to stress, in pregnant women is influenced by hormonal changes caused by their pregnancy. When these women failed to cope with anxiety triggered by stress, the high-stress level can cause hypertension and other complications, which can harm the mother or fetus. ${ }^{5}$

Depression and anxiety in pregnant women are very significantly related and affect fetal and neonatal growth. However, the apparent effect of maternal depression and anxiety on fetal-neonatal growth remains unclear. Also, research has found that depression and anxiety experienced by women during pregnancy will affect neonatal growth, behavior, and maturation outcomes. Neonates from mothers who experience prenatal depression or anxiety show a higher risk for preterm birth and low body weight, both of which are major health problems for neonates. ${ }^{8,9}$ Prenatal anxiety and depression are also associated with changes in brain structure and function in infants and children.

Depression during pregnancy is associated with many complications, such as premature birth, low birth weight, fetal growth disorder, and postnatal complications. ${ }^{4-5}$ It has also been linked to hypertension, preeclampsia, and gestational diabetes. ${ }^{4}$ Anxiety, depression, and stress during pregnancy are already serious health problems in healthy pregnant women in a normal environment. The current COVID-19 situation may become a stressor for pregnant women, especially when they do not have good knowledge on the disease. As pregnant women are very sensitive to stress and anxiety, there is a possibility of long-term mental complications from the COVID-19 pandemic among pregnant women. ${ }^{1}$

This study aimed to determine the level of anxiety in pregnant women in the Madura Region, East Java, Indonesia. Maduranese is known to be a conventional population that finds it difficult to receive inputs or changes, making them more prone to stress when there is a sudden change in their environment. In this population, many women are pregnant in an age that is either too young or too old thus they are not really ready to accept their pregnancy. Hence, a lot of pregnancies are already high-risk and the presence of COVID-19 pandemic adds to the risk cause by the possibility of being contracted by the disease and the anxiety caused by the fear of being contracted by the disease.

\section{Methods}

This descriptive study was performed on the pregnant women population in Madura, Indonesia, who were literate, had a smartphone, able to use Whatsapp messenger, and were willing to participate in the study. The study was conducted from April 13 to May 8, 2020. Participants were recruited through random distribution of a Google form to the pregnant women population in the area by involving the local midwives in the region. This mode of sampling was chosen due to the challenges 
of social distancing during the pandemic that prevented a face-to-face interview. Seventy pregnant women responded to the form during the period of study, consisting of 10 women from Sumenep, 10 from Pamekasan, 15 from Sampang, and 35 from Bangkalan. The distributed Google form consisted of informed consent and a questionnaire that is adopted from DASS (Depression, Anxiety, Stress Scale) which contained 11 questions. The adopted DASS questionnaire had been translated into the language easily understood by the population and it had been proven to be reliable and valid based on a previous study. This questionnaire collected data on the characteristics of pregnant women (age, education, occupation, gestational age) and anxiety using a 4-point Likert scale.

The study protocol has been approved by the Institute of Health Science Ngudia Husada Madura Ethics Commission under the ethical clearance No. 611/KEPK/STIKES-NHM/EC/ IV/2020.

Data collected were retrieved from the Google Form and then exported to Excel for further analysis. Scoring was performed and several variables were categorized. Data were then analyzed in cross-tabulation and frequency analysis using the SPPS version 24.0 for windows. Respondents were considered to have low anxiety level if the score was 6-7. Respondents with a score of 8-9 and more than 10 were considered to have a moderate level of anxiety and severe anxiety, respectively.

\section{Result}

Based on the analysis of data on the characteristics of pregnant women in Madura region it was revealed that $84 \%$ of pregnant women were 20-35 years old or in the productive age and safe age for pregnancy. The majority of the respondents graduated from junior high school $(52 \%)$, self-employed (42.9\%), were in their $2^{\text {nd }}$ to $4^{\text {th }}$ pregnancy $(71.4 \%)$, and were in their third trimester of pregnancy ( $>28$ weeks gestational age).

Analysis of the data showed that $31.4 \%$ of the pregnant women in Madura region experienced very severe anxiety due to the fear of being contracted by COVID-19 during this pandemic. The qualitative data collected through open questions in the questionnaire regarding antenatal visits during the COVID-19 pandemic showed that most women were scared and anxious to have their antenatal care examination
Table 1 Characteristics of Pregnant Women in Madura Region

\begin{tabular}{|c|c|c|}
\hline Variable & $(n=70)$ & $\%$ \\
\hline \multicolumn{3}{|l|}{ Age (years) } \\
\hline$<20$ & 3 & 4.3 \\
\hline $20-35$ & 59 & 84.3 \\
\hline$>35$ & 8 & 11.4 \\
\hline Total & 70 & 100 \\
\hline \multicolumn{3}{|l|}{ Education } \\
\hline No education & 2 & 2.9 \\
\hline Elementary school & 17 & 24.3 \\
\hline Junior high school & 37 & 52.9 \\
\hline Higher education & 14 & 20 \\
\hline \multicolumn{3}{|l|}{ Occupation } \\
\hline Unemployed & 24 & 34.3 \\
\hline Government officer & 10 & 15.7 \\
\hline Self-employed & 35 & 42.9 \\
\hline Farmers & 5 & 7.1 \\
\hline \multicolumn{3}{|l|}{ Parity } \\
\hline 1 & 17 & 24.3 \\
\hline $2-4$ & 50 & 71.4 \\
\hline$>4$ & 3 & 4.3 \\
\hline \multicolumn{3}{|l|}{ Gestational Age (weeks) } \\
\hline $0-12$ & 22 & 31.4 \\
\hline $13-28$ & 21 & 30 \\
\hline$>28$ & 27 & 38.6 \\
\hline
\end{tabular}

that some of them even decided no to have the examination. These women were anxious, scared, and worried about the presence of COVID-19. Those who were pregnant with the first child found it more stressful, which may relate to the hormonal changes and the adaptation process during the pregnancy and complaints of nausea, morning sickness, and other pregnancy-related

Table 2 Anxiety in Pregnant Women During COVID-19 Pandemic

\begin{tabular}{lcc}
\hline Variable & $(\mathbf{n = 7 0 )}$ & \% \\
\hline Anxiety & & \\
No anxiety & 14 & 20 \\
Low anxiety & 13 & 18.6 \\
Moderate & 12 & 17.1 \\
Severe & 31 & 44.3 \\
\hline
\end{tabular}


complaints that had never been experienced before, thus already create anxiety even before they learned about the presence of the pandemic.

\section{Discussion}

Based on the analysis in this study, most pregnant women experienced severe anxiety due to the presence coronavirus pandemic (44.3\%). A report from the World Health Organization stated that about $10 \%$ of pregnant women experience a mental disorder, primarily depression. In developing countries, the prevalence is even higher, reaching $15.6 \%$ during pregnancy and $19.8 \%$ after childbirth. Something unexpected or unknown will make this anxiety heightened. This anxiety is contributed, in part, by the physiological changes in trimesters 1,2 , and 3 triggered by the hormonal changes experienced by pregnant women, which sill cause emotional changes and mood swings. ${ }^{11}$

Husband and family support is needed during pregnancy. Social support can buffer the effects of prenatal stress and has been shown to mitigate the impacts of prenatal anxiety and depression symptoms on maternal and infant stress response systems. Physical activity is also associated with reduced depressive and anxiety symptoms in pregnant women. Excessive anxiety in pregnant women might cause pathological anxiety that may lead to complications for the mother and the fetus. The presence of this coronavirus pandemic increases the anxiety and triggers excessive fear among pregnant women due to the lack of knowledge and exposure to misinformation or disinformation regarding the pandemic. $^{10,12}$

Pregnant women who often have such anxiety and fear will have their work of the sympathetic nervous system increases. The sympathetic nervous system releases hormones into the bloodstream to prepare the body for emergencies. The autonomic nervous system then activates the adrenal glands which affect the system on the hormone epinephrine and increases adrenaline. The increased in adrenaline will cause biochemical dysregulations of the body, resulting in physical tension in the pregnant woman and increasing the overall emotional intensity. ${ }^{11}$ Previous studies have shown that when pregnant women experience psychological stress such as depression, anxiety, and/or stress during pregnancy, the risk of premature birth will increase and the familial bonds/attachment between mother and child will be hampered. This also causes post-partum psychological disorders and infant growth disorders that manifest in low birth weight. ${ }^{13,14}$

A study by Durankus ${ }^{4}$ illustrated the effects of the COVID-19 pandemic on depression and increased anxiety levels in pregnant women. The findings of this study have emphasized the urgent need for counseling and assistance for pregnant women to prevent adverse effects of anxiety and depression that will eventually affect the mother and fetus. The emotional expressions of stress in pregnant women includes mood swings that can be used as a sign that the woman needs counseling and assistance..$^{15}$

Counseling and distribution of correct information on coronavirus or COVID-19 to pregnant women can be done by the midwife who attends these women, both through home visit or by creating a WhatsApp group to provide information and support regarding pregnancy and to reduce excessive anxiety which will have fatal consequences for the mother and her fetus.

This study has a limitation as it only used Google form to collect data, meaning that there is no control from the researcher on how the respondents filled out the data. The number of pregnant women participating in this study was also small $(n=70)$ because some pregnant women could be reached through this method due to the fact that they do not use smartphone or have WhatsApp application installed.

In conclusion, a quite high percentage of pregnant women in the Madura experiences severe anxiety in the presence of the COVID-19 pandemic (31.4\%). Counseling and distribution of correct information on the pandemic to pregnant women is mandatory and can be done through home visits by midwives or through creating a WhatsApp group managed by the midwife. This is necessary to check on the pregnancy condition and reduce excessive anxiety which will have fatal consequences for the mother and her fetus. Pregnant women should not visit health care facilities to have examination with the midwife except in emergencies such as bleeding, rupture of membranes, seizures, and signs of childbirth. When it is unavoidable that they should have examination, they must pay attention to the COVID-19 prevention protocol by wearing a mask/face shield, washing hands or using a hand sanitizer. It is also recommended that pregnant women should do light exercise or pregnancy exercise at home. Further studies with a larger sample size should be conducted to better understand anxiety among pregnant women amid the COVID-19 pandemic. 


\section{References}

1. Rasmussen SA, Smulian JC, Lednicky JA, Wen TS, Jamieson DJ. Corona disease 2019 (COVID-19) and pregnancy: what obstetricians need to know. Am J Obstet Gynecol. 2020;222(5)1-12.

2. Liang $\mathrm{H}$, Acharya G. Novel coronavirus disease (COVID-19 ) in pregnancy: What clinical recommendations to follow? (Ultrasound Obstet Gynecol 2020) 2020;99;(4):439-42.

3. Yang H, Wang C, Poon LC. Opinion: Novel coronavirus infection and pregnancy. Ultrasound Obstet Gynecol. 2020;55(4):435437.

4. Durankuş F, Aksu E. Effects of the COVID-19 pandemic on anxiety and depressive symptoms in pregnant women: a preliminary study. J Matern Neonatal Medicine. 2020;44(7):1-7.

5. Ciesielski TH, Marsit CJ, Williams SM. Maternal psychiatric disease and epigenetic evidence suggest common biology for poor fetal growth. BMC Pregnancy Childbirth. 2015;15(1):192.

6. Grigoriadis S, VonderPorten EH, Mamisashvili L, Tomlinson G, Dennis CL, Koren G, et al. The impact of maternal depression during pregnancy on perinatal outcomes: a systematic review and meta-analysis. J Clin Psychiatry. 2013;74(4):e321-41.

7. Wahyuningsih HP, Tyastuti S. Modul, bahan ajar, praktikum asuhan kebidanan kehamilan, Kementerian Kesehatan Republik Indonesia; Pusat Pendidikan Sumber Daya Manusia Kesehatan; Badan Pengembangan Dan Pemberdayaan Sumber Daya Manusia Kesehatan; 2016.

8. Aprisandityas A, Elfida D. Hubungan antara regulasi emosi dengan kecemasan pada ibu hamil, J Psikol UIN Sultan Syarif Kasim Riau.
2012;8(2)80-9.

9. Rajeswari S, SanjeevaReddy N. Efficacy of Progressive Muscle Relaxation on Pregnancy Outcome among Anxious Indian Primi Mothers. Iran J Nurs Midwifery Res. 2019;25(1):23-30.

10. Schwartz DA. An analysis of 38 pregnant women with COVID-19, their newborn infants, and maternal-fetal transmission of sars-cov-2: maternal coronavirus infections and pregnancy outcomes [published online ahead of print, 2020 mar 17]. Arch Pathol Lab Med. 2020;10.5858/arpa.2020-0901SA.

11. Schwartz DA, Graham AL. Potential maternal and infant outcomes from (wuhan) coronavirus 2019-nCoV infecting pregnant women: lessons from SARS, MERS, and other human coronavirus infections. Viruses. 2020;12(2):194.

12. Diani LPP, Susilawati, KPA. Pengaruh dukungan suami terhadap istri yang mengalami kecemasan pada kehamilan trimester ketiga di Kabupaten Gianyar. Jurnal Psikologi Udayana. 2013;1(1):1-11.

13. Wu Y, Lu YC, Jacobs M, Pradhan S, Kapse K, Zhao L, etal. Association of prenatal maternal psychological distress with fetal brain growth, metabolism, and cortical maturation. JAMA Netw Open. 2020;3(1):e1919940.

14. Staneva A, Bogossian F, Pritchard M, Wittkowski A. The effects of maternal depression, anxiety, and perceived stress during pregnancy on preterm birth: A systematic review. Women and Birth. 2015;28(3)179-93.

15. Guille C, Newman RB, editors. Clinics review article perinatal mental health; obstetrics and gynecology clinics of North America. Amsetrdam: Elsevier; 2018. 